\title{
Study on Interaction of Earthworm with Bioagents during Vermicomposting
}

\author{
Sujan Biswas ${ }^{1 *}$, Surajit Sarkar ${ }^{1}$, Augustina Saha ${ }^{2}$, Sankar Saha ${ }^{1}$ and F.H. Rahman ${ }^{3}$ \\ ${ }^{1}$ Cooch Behar Krishi Vigyan Kendra, Uttar Banga Krishi Vishwavidyalaya, \\ Cooch Behar-736165, West Bengal, India \\ ${ }^{2}$ SRF, NICRA Project, Cooch Behar Krishi Vigyan Kendra, Uttar Banga Krishi \\ Vishwavidyalaya, Cooch Behar, 736165, West Bengal, India \\ ${ }^{3}$ ICAR-Agricultural Technology Application Research Institute, Kolkata, West Bengal, India
}

*Corresponding author

\section{A B S T R A C T}

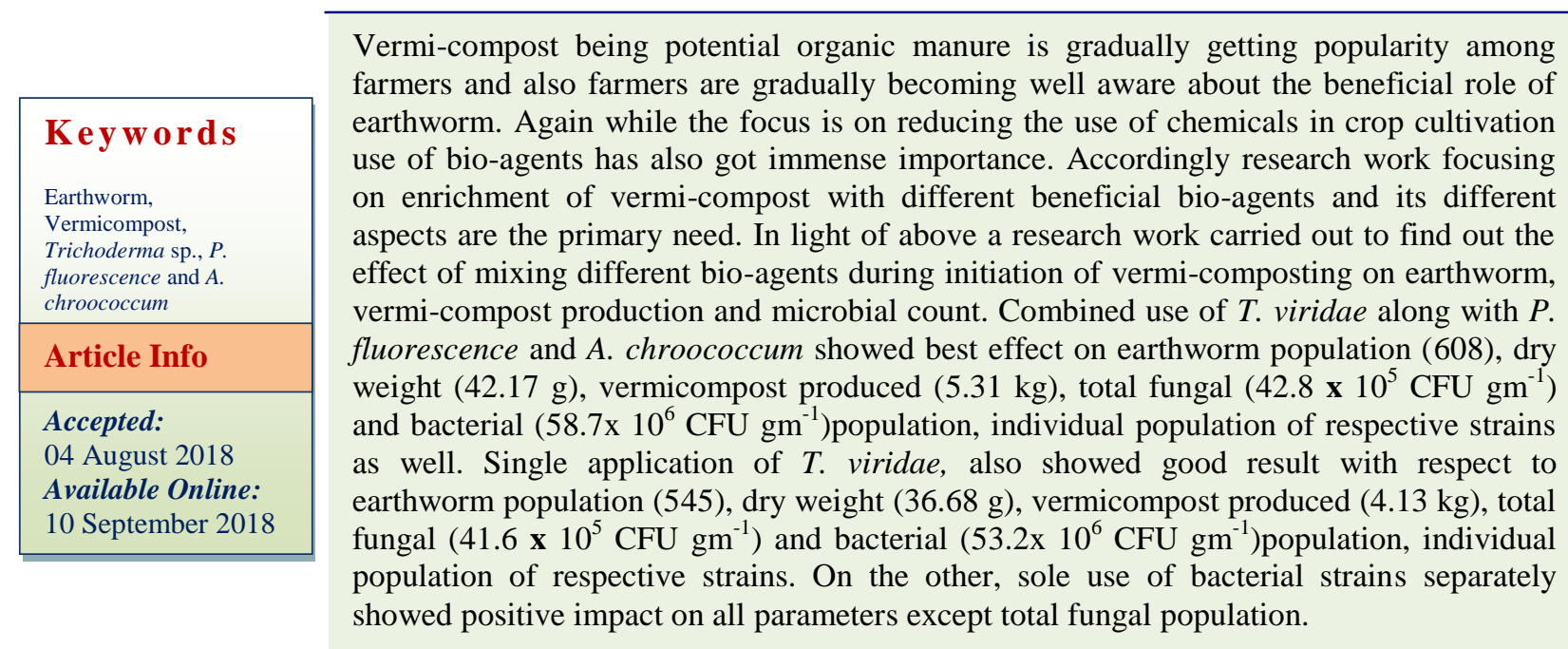

\section{Introduction}

Soil health is undoubtedly the focus area of concern to the scientist working in the field of soil science and resisting gradual soil degradation or maintaining good soil health for long time or improving soil health over the period without hampering the ecological balance is the foremost target to achieve or develop efficient and eco-friendly sustainability in agriculture system. Now a days scientists envisaging for maximum use of organic manure and bio-fertilizer while minimizing the use of chemical fertilizer.

Vermi-compost, a type of organic manure prepared through the eco-friendly process of converting organic materials into compost by 
action of earthworm, reported to contain increased levels of both macro and micro nutrients in available form, enzymes, micro flora and growth regulators (Edwards, 2004 and Ansari, 2011). Because of all these beneficial effects vermin-compost when applied in soil improved crop growth and yield. Further to note that role of earthworm in maintenance of the sustainability has already been recognized by many scientists like M. S. Swaminathan in his monographic work: Stockholm to Rio to sustainable agriculture. The earthworms, apart from its role in vermincomposting helps to sustain soil health by regulating many processes in soil, and also play key role to reduce contamination of metals in soil by enhancing phytoextraction of metals from contaminated soils (Sinha et al., 2010). Vermi-compost as a potential organic manure is gradually getting popularity among farmers of the country and farmers are also gradually becoming well aware about the beneficial role of earthworm.

On the other hand another important component for marching towards organic farming-bio-fertilizers are also reported to play several beneficial roles in soil like taking part in biological nitrogen fixation, solubilization of essential minerals, get hold of nutrients, offering micronutrients in more utilizable form for plants and suppressing disease infestation. Soil bacteria are an important source of nutrients for earthworms (Tiunov and Scheu, 2004) and protein requirement of earthworms is also fulfilled by these microorganisms (Wright, 1972 and Agrawal, 1999).

Edwards and Fletcher, 1988, reported an increased count of fungi, bacteria and actinomycetes in vermicompost as compared to the soil (Tiunov and Scheu, 2004). The increase in microbial count and growth may be attributed towards ingestion of these microorganisms along with organic wastes by earthworms which provide suitable environment and substrate to feed for microbial organisms (Tiwari et al., 1989). Plant growth promoting microorganisms (PGPMs) which include Azospirillum, Azotobacter, phosphobacteria, Rhizobia etc. encourage crop growth and yield by biological nitrogen fixation, solubilization of essential minerals, get hold of nutrients, offering micronutrients in more utilizable form for plants (Barassi et al., 2007; Abo-Baker and Mostafa, 2011; Geetha and Balamurugan, 2011). Rhizosphere fungi and bacteria like Trichoderma, Pseudomonus etc. promote plant growth by improving the availability of nutrients suppressing the growth of plant pathogens or by production of hormones such as auxins (Jangu and Sindhu, 2011). In spite of so many beneficial roles of beneficial microbes popularization of bio-fertilizer in agriculture is still at its very infant level and separate lone use of bio-fertilizer in agriculture by farming community is observed to be very limited due to several constraints like lack of awareness, unavailability of standard quality bio-fertilizer, care and precautions required before application to the field etc. Considering the increased awareness about beneficial roles of vermi-compost among farmers of the country and its increased application in soil against that of gloomy picture in case of bio-fertilizer; attention are now being paid by the scientist to enrich vermicompost with different microorganisms. Recently, Raja Sekar and Karmegam (2010) reported that the vermicasts are able to increase the survival rate of biofertilizer organisms for more than a year when used as carrier material. Aira et al., in the year 2006 reported that vermicomposting is a suitable system for studying microbe earthworm interaction. Very few research works have been carried out to find out the effect of bio-agents on earthworm population and vermicompost production when added during the initiation of vermicomposting 
process. Furthermore reports on interaction between earthworm and externally added bioagents are still not available to the desired extent. In light of above an experiment was designed with the objective to study the interaction between some beneficial bioagents and earthworm i.e. the effect of bioagents on earthworm population, vermicompost production and vice versa the effects of earthworm on bio-agents population.

\section{Materials and Methods}

\section{Experimental site and condition}

The experiment was conducted from June to August, 2014, at demonstration unitsof Cooch Behar Krishi Vigyan Kendra, Uttar Banga Krishi Viswavidyalaya located at Pundibari, Cooch Behar, West Bengal. The experiment was conducted at partially controlled condition. Maximum and minimum temperature during the process of vermicomposting under the demonstration unit as recorded was $27-31^{\circ} \mathrm{C}$ and $22-26^{\circ} \mathrm{C}$.

\section{Vermicompost preparation}

Cow dung and water hyacinth were mixed at 1:1 ratio on equivalent moisture content basis in concrete chamber and allowed to decompose for 30 days to use as feed material of earthworm. The process of vermicomposting was carried out in round earthen pot locally called chari in partially controlled condition. $15 \mathrm{~kg}$ of partially decomposed feed material on $40 \%$ w/w basis was taken in each pot and different strains of bio-fertilizer@5 gm kg-1 of feed material were mixed well with feed materials of earthworm and then 40 numbers of earthworm added. Earthworm species Eiseniafoetida was collected from demonstration centre of Cooch Behar Krishi Vigyan Kendra, Uttar Banga Krishi Viswavidyalaya. Strains of bio-fertilizer were collected from Department of Plant Pathology, Uttar Banga Krishi Viswavidyalaya. 60-70\% (w/w) moisture content was maintained during vermin-composting period by sprinkling water at every 2 days interval. After 50 days of vermicomposting, earthworm population was counted and amount of vermicompost produced was measured. Samples were also collected for counting of bio-agent population at laboratory.

\section{Experimental design}

Strains of fungi namely Trichoderma $s p$. (local), Trichoderma viridae and strains of bacteria namely, Pseudomonus fluorescence and Azotobactor chroococcum either singly or in different combination were mixed well with feed material@ $5 \mathrm{gm} \mathrm{kg}^{-1}$ of feed material alomg with control pot to constitute 9 treatments.

The earthen pot wherein vermicomposting was carried out without addition of any bioagent strain was treated as control. Details of treatments were as follows : $\mathrm{T}_{1}$ - Control, $\mathrm{T}_{2}$ - Trichoderma sp. (local), $\mathrm{T}_{3}$ Trichoderma viridae, $\mathrm{T}_{4}$ - Pseudomonus fluorescence, $\mathrm{T}_{5}-$ Azotobactor chroococcum, $\mathrm{T}_{6}$ - Trichoderma sp. (local) + Pseudomonus fluorescence, $\mathrm{T}_{7}$-Trichoderma sp. (local) + Azotobactor chroococcum, $\mathrm{T}_{8}-$ Trichoderma viridae + Pseudomonus fluorescence, $\mathrm{T}_{9}-$ Trichoderma viridae + Azotobactor chroococcum. Each treatment was replicated thrice.

Samples were collected during harvesting of vermicompost from all treatment replications for immediate microbial analysis- count of total bacteria, fungi and individual species used in the experiment.

Samples were cultured in modified nutrient agar medium (Rangaswami, 1966) for bacteria, Martins Rose Bengal agar medium 
(Martin, 1950) for fungi and total number of bacteria and fungi were estimated by "Serial dilution plate method" (Allen, 1953; Kannan, 1996).

For isolation and counting of Pseudomonas fluorescence, the method proposed by Vlassak et al., (1992) was followed in which samples were treated with normal saline, serially diluted upto $10^{-6}$ times followed by incubation of suitable amount of aliquot at petri plate containing specific media i.e., King's B at room temperature $\left(28^{0} \mathrm{C} \pm 2{ }^{0} \mathrm{C}\right)$ for $24-72$ hours. The plates were examined daily up to 3 days for bacterial colonies.

For counting of Azotobacter chroococcum, samples were cultured in Modified Ashby's medium (Abd-el-Malek and Ishac, 1968) followed by $\mathrm{pH}$ adjustment to 7.0, incubation at $28^{0} \mathrm{C}$ for 72 hour, sterilization for 20 minutes at $121^{\circ} \mathrm{C}$ and counting of Azotobacter chroococcum cells with the help of a hemocytometer under the microscope.

For counting of fungal species Trichoderma viride, samples were cultured in potato dextrose agar (PDA) medium (Gamal et al., 2007), incubated at $26^{\circ} \mathrm{C}$ for 4 days in plates.

The fungal colonies were picked up and purified by streaking were incubated at $26^{\circ} \mathrm{C}$ for 7-8 days. Counting of green conidia forming fungal bodies of Trichoderma viride was done under the microscope. For Trichoderma spp. (local), dilution plate count technique was applied (Hirte, 1969) cultured in potato dextrose agar (PDA) medium.

\section{Statistical analysis}

One way ANOVA was done to determine the significance among the parameters - amount of vermicompost produced, earthworm population and bio-agent population using the software SAS (SAS Institute Inc. 1990)

\section{Results and Discussion}

\section{Effect of bio-agents on vermicompost production and earthworm population}

In the present investigation, two strains of fungal bioagents and two strains of bacterial bioagents were used. All the treatments in the experiment showed positive effect on earthworm and vermicompost production except the treatments with Trichoderma $s p$. (local) over control. While comparing, among treatments with sole application of a bioagent it was noted that bacterial strain $P$. fluorescence had most significant positive effect on earthworm population (598 nos.) and dry weight (40.86 g) immediately followed by A. chroococcum (591 nos. and 39.92) and both were significantly higher that control treatment (513 nos. and $32.24 \mathrm{~g}$ ). On the other hand, among fungal bio-agent, $T$. viridae showed positive effect on earthworm population (545 nos.) and dry weight (36.68 g); whereas strains of Tricoderma sp. (local) had a negative effect on earthworm population (407 nos.) and dry weight (25.52 g). Bacterial bioagents when applied in combination with Trichoderma sp. (local), it was noted that both $P$. fluorescence and $A$. chroococcum significantly reduces the intensity of negative impact of Trichoderma sp. (local) on earthworm and conversely Trichoderma $s p$. (local)very significantly reduces the intensity of positive impact of $P$. fluorescence and $A$. chroococcum on earthworm population (463 and 472 nos.) and dry weight (28.96 $\mathrm{g}$ and $30.01 \mathrm{~g})$, thereby indicating an antagonistic relationship between the fungal and bacterial strains. Interestingly, it was observed when bacterial strains $P$. fluorescence and $A$. chroococcum were used in combination with fungal bioagent $T$. viridae, count of earthworm population (608 nos. and 602 nos.) and dry weight $(42.17 \mathrm{~g}$ and $41.49 \mathrm{~g})$ were significantly higher than respective treatments with sole application of these three bioagents 
(598 nos. \& 40.86 g, 591 nos. \& $39.92 \mathrm{~g}$ and 545 nos. \& $36.68 \mathrm{~g}$, respectively), which signifies a synergistic relationship between the fungal and bacterial strains used in the experiment. Higher numbers of earthworm population and dry weight with treatments can be explained by better decomposition of organic materials used as feed in presence of added microbial agents and difference in effect might be due to varying capacity of bioagents to decompose organic matter (Campbell, 1983) (Table 1).

Further, higher earthworm population and dry weight in presence of bacteria can also be explained by the fact that bacteria are important source of nutrients (Tiunov and Scheu, 2004) and protein for earthworm (Wright, 1972). However, further investigation is needed to explain the reverse effect of locally collected Trichoderma strains.

Dry weight of vermicompost obtained in the process also followed the similar trend as in case of earthworm population and dry weight. Bioagent combination of $T$. viridae $+P$. fluorescence $(5.31 \mathrm{~kg})$ recorded highest production which was at par with treatment with bio-agents $T$. viridae $+A$. chroococcum $(5.29 \mathrm{~kg})$ and both these treatment combinations are significantly superior than rest of the treatments.

Keeping parity with the result in case of earthworm treatment with local bioagent of Trichoderma sp. recorded lowest production of vermicompost $(3.33 \mathrm{~kg})$.

Increase in earthworm population during the process of vermicomposting indicates that microbial communities used the available energy more efficiently in the presence of earthworms. As a consequence, the system functioned much better, as shown higher dry weight of vermicompost produced during the process.
Interaction effect of bioagents during vermicomposting

A critical observation of data presented in Table 2, showed positive effect on total fungal and bacterial population, except a few. Significantly higher total fungal population over control $\left(\mathrm{T}_{1}: 36.1 \times 10^{5} \mathrm{CFU} \mathrm{gm}^{-1}\right)$ was recorded in treatments with $T$. viridae, either singly $\left(\mathrm{T}_{3}: 41.6 \mathrm{x} \quad 10^{5} \mathrm{CFU} \mathrm{gm}^{-1}\right)$ or in combination with $P$. fluorescence $\left(\mathrm{T}_{8}: 42.8 \mathrm{x}\right.$ $\left.10^{5} \mathrm{CFU} \mathrm{gm}^{-1}\right)$ and A. chroococcum $\left(\mathrm{T}_{9}: 42.5 \mathrm{x}\right.$ $10^{5} \mathrm{CFU} \mathrm{gm}^{-1}$ ) and differences among treatments were statistically at par with each other. Effect of Trichoderma sp. (local) on total fungal population, although not so prominent like $T$. viridae; still it showed positive effect over control on total fungal count when applied singly $\left(\mathrm{T}_{2}: 39.2 \times 10^{5} \mathrm{CFU}\right.$ $\mathrm{gm}^{-1}$ ) in combination with $P$. fluorescence $\left(\mathrm{T}_{6}: 39.8 \times 10^{5} \mathrm{CFU} \mathrm{gm}^{-1}\right)$ and $A$. chroococcum $\left(\mathrm{T}_{7}: 40.3 \times 10^{5} \mathrm{CFU} \mathrm{gm}^{-1}\right)$ of which effect of combined application of Trichoderma $s p$. (local) with bacterial strain differ significantly over control. No significant effect of $P$. fluorescence and A. chroococcum on total fungi population was observed when treatments with sole application of $P$. fluorescence ( $\left.\mathrm{T}_{4}: 36.9 \times 10^{5} \mathrm{CFU} \mathrm{gm}^{-1}\right)$ and $A$. chroococcum $\left(\mathrm{T}_{5}: 37.2 \times 10^{5} \mathrm{CFU} \mathrm{gm}^{-1}\right)$ were compared with control $\left(\mathrm{T}_{1}: 36.1 \times 10^{5} \mathrm{CFU}\right.$ $\left.\mathrm{gm}^{-1}\right)$. A comparison of population of Trichoderma sp. (local) among treatments used in the experiment indicated no clear cut trend in effect of earthworm on Trichoderma $s p$. (local). It was observed that only treatments with Trichoderma sp. (local) either singly $\left(\mathrm{T}_{2}: 5.4 \times 10^{5} \mathrm{CFU} \mathrm{gm}^{-1}\right)$ or in combination with $P$. fluorescence $\left(\mathrm{T}_{6}: 5.1 \mathrm{x}\right.$ $\left.10^{5} \mathrm{CFU} \mathrm{gm}^{-1}\right)$ and $A$. chroococcum $\left(\mathrm{T}_{7}: 5.0 \mathrm{x}\right.$ $10^{5} \mathrm{CFU} \mathrm{gm}^{-1}$ ) had significantly better population over control $\left(\mathrm{T}_{1}: 4.3 \times 10^{5} \mathrm{CFU}\right.$ $\mathrm{gm}^{-1}$ ) while rest of the treatments i.e. treatments without Trichoderma sp. (local) found to have no significant differences with control. 
Table.1 Effect of bio-agents on vermi-compost production and earth worm population

\begin{tabular}{|l|} 
Treatments \\
\hline T1 \\
\hline T2 \\
\hline T3 \\
\hline T4 \\
\hline T5 \\
\hline T6 \\
\hline T7 \\
\hline T8 \\
\hline T9 \\
\hline LSD $(5 \%)$ \\
\hline
\end{tabular}

\begin{tabular}{|c|c|c|}
\hline \multicolumn{2}{|c|}{ Earthworm } & $\begin{array}{c}\text { Dry weight of } \\
\text { vermicompost (kg) }\end{array}$ \\
\hline 513 & 34.24 & 3.73 \\
\hline 407 & 25.52 & 3.33 \\
\hline 545 & 36.68 & 4.13 \\
\hline 598 & 40.86 & 5.10 \\
\hline 591 & 39.92 & 4.87 \\
\hline 463 & 28.96 & 3.67 \\
\hline 472 & 30.01 & 3.69 \\
\hline 608 & 42.17 & 5.31 \\
\hline 602 & 41.49 & 5.29 \\
\hline 49 & 3.03 & 0.35 \\
\hline
\end{tabular}

Table.2 Fungal population (x $\left.10^{5} \mathrm{CFU} \mathrm{gm}^{-1}\right)$ under different treatments

\begin{tabular}{|l|}
\hline \multicolumn{1}{|c|}{ Treatment } \\
\hline T1 \\
\hline T2 \\
\hline T3 \\
\hline T4 \\
\hline T5 \\
\hline T6 \\
\hline T7 \\
\hline T8 \\
\hline T9 \\
\hline LSD $(5 \%)$ \\
\hline
\end{tabular}

\begin{tabular}{|c|c|c|}
\hline Trichoderma sp & Trichoderma viridae & Total \\
\hline 4.3 & 2.4 & 36.1 \\
\hline 5.4 & 1.8 & 39.2 \\
\hline 4.0 & 6.7 & 41.6 \\
\hline 3.9 & 3.1 & 36.9 \\
\hline 4.1 & 3.3 & 37.2 \\
\hline 5.1 & 1.9 & 39.8 \\
\hline 5.0 & 2.0 & 40.3 \\
\hline 3.8 & 7.2 & 42.8 \\
\hline 3.9 & 7.1 & 42.5 \\
\hline 0.53 & 0.59 & 3.7 \\
\hline
\end{tabular}

Table.3 Bacterial population $\left(\times 10^{6} \mathrm{CFU} \mathrm{gm}^{-1}\right)$ under different treatments

\begin{tabular}{|l|c|c|c|}
\hline Treatment & Pseudomonas fluorescence & Azotobactor chroococcum & Total \\
\hline T1 & 2.6 & 2.1 & 46.4 \\
\hline T2 & 2.1 & 1.9 & 42.4 \\
\hline T3 & 3.9 & 2.9 & 53.2 \\
\hline T4 & 7.2 & 2.9 & 56.1 \\
\hline T5 & 3.6 & 7.2 & 55.4 \\
\hline T6 & 5.2 & 1.4 & 49.5 \\
\hline T7 & 1.9 & 5.7 & 51.1 \\
\hline T8 & 8.4 & 2.5 & 58.7 \\
\hline T9 & 2.8 & 8.1 & 58.9 \\
\hline LSD (5\%) & 0.41 & 0.39 & 4.51 \\
\hline
\end{tabular}


On the other hand, highest population of $T$. viridae was recorded in treatment where $T$. viridae was applied in combination with $P$. fluorescence $\left(\mathrm{T}_{8}: 7.2 \times 10^{5} \mathrm{CFU} \mathrm{gm}^{-1}\right)$ and $A$. chroococcum ( $\mathrm{T}_{9}: 7.1$ x $10^{5}$ CFU $\mathrm{gm}^{-1}$ ) followed by treatment with sole application of T. viridae $\left(\mathrm{T}_{3}: 6.7 \times 10^{5}\right.$ CFU $\left.\mathrm{gm}^{-1}\right)$. Interestingly, it was noted that treatment with sole application of Trichoderma sp. (local) recorded significantly lower population of $T$. viridae over control $\left(\mathrm{T}_{1}: 2.4 \times 10^{5} \mathrm{CFU} \mathrm{gm}^{-1}\right)$. On the other, treatments wherein $P$. fluorescence and A. chroococcum were applied singly, showed positive effect on population of $T$. viridae $\left(\mathrm{T}_{4}: 3.1 \times 10^{5} \mathrm{CFU}\right.$ $\mathrm{gm}^{-1}$ and $\mathrm{T}_{5}: 3.3 \mathrm{x} 10^{5} \mathrm{CFU} \mathrm{gm}^{-1}$ ). Combination of Trichoderma sp. (local) with bacterial strains suppresses the positive influence of both strain on population of $T$.

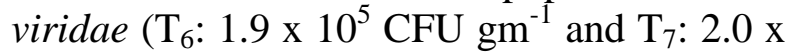
$10^{5}$ CFU $\left.\mathrm{gm}^{-1}\right)$. The increased fungal population might be due to the availability of nutrient rich organic waste and increase surface area of ingested waste by mechanical action of earthworm (Edwards et al., 1985).

Total bacterial population as presented in Table 3, showed that higher bacterial population was recorded in all treatments over control except the treatment $\left(\mathrm{T}_{2}: 42.4 \times 10^{6}\right.$ CFU $\mathrm{gm}^{-1}$ ) with sole application of Trichoderma sp. (local). Highest total bacterial population was recorded in treatments where $T$. viridae was applied in combination with $P$. fluorescence $\left(\mathrm{T}_{8}: 58.7 \times\right.$ $10^{6} \mathrm{CFU} \mathrm{gm}^{-1}$ ) and A. chroococcum ( $\mathrm{T}_{9}: 58.9$

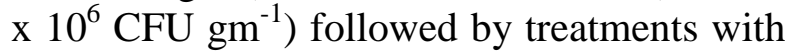
sole application of $P$. fluorescence $\left(\mathrm{T}_{4}: 56.1 \mathrm{x}\right.$ $\left.10^{6} \mathrm{CFU} \mathrm{g^{-1 }}\right)$, A. chroococcum $\left(\mathrm{T}_{5}: 55.4 \mathrm{x}\right.$ $\left.10^{6} \mathrm{CFU} \mathrm{gm}^{-1}\right)$ and $T$. viridae $\left(\mathrm{T}_{3}: 53.2 \times 10^{6}\right.$ CFU $\mathrm{gm}^{-1}$ ) and all were significantly higher than control $\left(\mathrm{T}_{1}: 46.4 \times 10^{6} \mathrm{CFU} \mathrm{gm}^{-1}\right)$. Significant reduction in total bacterial count was observed when P. fluorescence and A. chroococcum was applied in combination with Trichoderma sp. (local), thereby indicating a negative impact on total bacterial population in vermicompost produced. Highest population of $P$. fluorescence was recorded in treatment where $P$. fluorescence was applied in combination with $T$. viridae $\left(\mathrm{T}_{8}: 8.4 \times 10^{6} \mathrm{CFU} \mathrm{gm}^{-1}\right)$ followed by treatment with sole application of $P$. fluorescence $\left(\mathrm{T}_{4}: 7.2 \times 10^{6} \mathrm{CFU} \mathrm{gm}^{-1}\right)$. A comparison among treatments with sole application of Trichoderma sp. (local), P. fluorescence and their combined application further indicated that Trichoderma sp. (local) suppressed the positive effect of the bacterial strain and vis-a-vis. Likewise, highest population of $A$. chroococcum was recorded in treatment where $A$. chroococcum was applied in combination with $T$. viridae $\left(\mathrm{T}_{9}: 8.1\right.$ $\mathrm{x} 10^{6} \mathrm{CFU} \mathrm{gm}^{-1}$ ); which was immediately followed by treatment where the strain was applied solely $\left(\mathrm{T}_{5}: 7.2 \times 10^{6} \mathrm{CFU} \mathrm{gm}^{-1}\right)$. Similar to interaction of Trichoderma $s p$. (local) and P. fluorescence, a comparison of treatments with sole application of Trichoderma sp. (local), A. chroococcum and their combined application further indicated that Trichoderma sp. (local) suppressed the positive effect of the bacterial strain and visa-vis.

Similar increases were also observed in other vermicomposts by Karmegam and Daniel (2009), Prakash et al., (2009), Edwards et al., (1988), Tiunov and Scheu (2004). The increase in microbial count and growth may be attributed towards ingestion of these microorganisms along with organic wastes by earthworms which provide suitable environment and substrate to feed for microbial organisms (Tiwari et al., 1989). The study conducted by Rao et al., (2012) also reported increased bacterial count due to the presence of earthworm which they explained was due to the fact that earthworm act as good supporters for microbial growth by providing larger surface area by digesting and degrading organic material into smaller pieces and 
providing facility for proper aeration; thereby providing favourable medium for bacterial growth.

Bacterial strain $P$. fluorescence, $A$. chroococcum and fungal strain $T$. viridae had positive impact on earthworm population, weight and amount of vermicompost produced; whereas the fungal strain Trichoderma sp. (local) exerted a negative impact. Positive influence of bacterial strains on earthworm and vermicompost was more pronounced than the fungal strain $T$. viridae. In reference to effect on earthworm count, weight and vermicompost production- a synergistic relationship among fungal strain $T$. viridae and both bacterial strains was observed; whereas, bacterial strains had an antagonistic relationship with Trichoderma $s p$. (local). Use of $T$. viridae greatly improved total fungal population as well as population of the applied strain in the vermicompost. Further, application of bacterial strain $P$. fluorescence and A. chroococcum showed significant improvement in total bacterial count and also their individual population. Moreover, the fungal species $T$. viridae also had a positive and Trichoderma sp. (local) had a negative impact on total bacterial population and even individual population of bacterial strains used in the experiment.

\section{References}

Abd-el-Malek, Y., Ishac Y. 1968. Evaluation of Methods Used in Counting Azotobacters. Journal of Applied Bacteriology. 31 (3): 267-275.

Abo-Baker, A. A. and Mostafa, G. G. 2011. "Effect of bio-and chemical fertilizers on growth, sepals yield and chemical composition of Hibiscus sabdariffaat new reclaimed soil of South Valley area," Asian Journal of Crop Science, 3(1) :1625 ,

Agrawal, S. 1999. Study of vermicomposting of domestic waste and the effects of vermicompost on growth of some vegetable crops. Ph.D. Thesis, University of Rajasthan, Jaipur.

Aira M, Monroy F, Dominguez J. 2006. Eiseniafoetida (Oligocheta, Lumbricidae) activates fungal growth triggering cellulose decomposition during vermicomposting. Microb. Ecol. 52:738747.

Allen G.N. 1953. Experiments in soil bacteriology, Burgers Publ. Co., Minnepolis, Minn., U.S.A. p. 127.

Ansari, A. A. 2011. "Worm powered environmental biotechnology in organic waste management," International Journal of Soil Science. 6(1): pp. 25-30.

Barassi, C. A., R. J. Sueldo, C.M. Creus, L. E. Carrozzi, E. M. Casanovas, and M. A. Pereyra, 2007. "Azospirillum spp., a dynamic soil bacterium favourable to vegetable crop production," Dynamic Soil, Dynamic Plant. 1(2): 68-82.

Campbell, D. J., Fox, W. E., Aitken, R. L. and Bell, L. C. 1983. Physical characteristics of sands amended with flyash, Aust. J. Soils Res. 21:147 154.

Daniel, O., Anderson, J. M. 1992. Microbial biomass and activity in contrasting soil materials after passage through the gut of the earthworm Lumbricus rubellus Hoffmeister. Soil Biology and Biochemistry. 24:465-470.

Edwards CA, Burrows I, Fletcher KE, Jones BA (1985). The use of earthworms for composting farm wastes. In: Gasser JKR (ed) Composting Agricultural and Other Wastes, Elsevier, London. Pp: 229-241.

Edwards, C. A. 2004. Earthworm Ecology, CRC Press, Boca Raton, Fla, USA, 2nd edition.

Edwards, C. A., Fletcher, K. E. 1988. Interactions between earthworms and microorganisms in organic matter breakdown. In: Edwards, C. A., Stinner, B. R., Stinner, D., Rabatin, S. (eds.). Biological Interactions in Soil. Elsevier, New York, pp. 235-247. 
Gamal, M. Abdel-Fattah, Yasser M. Shabana, Adel E. 2007. T. harzianum: Mycopathology. 164: 81-89.

Geetha, V. V. and P. Balamurugan. 2011. "Organic seed pelleting in mustard," Research Journal of Seed Science. 4(3): 174-180.

Hirte, W.F 1969. The use of dilution plate method for the determination of soil microflora. The qualitative demonstration of bacteria and actinomycetes. Zentrall Bakteriol Parasitenkd Infektionskr Hyg, 123 (2): 167-178.

Jangu, O. P. and S. S. Sindhu. 2011. "Differential response of inoculation with indole acetic acid producing Pseudomonas sp. in green gram (Vigna radiate L.) and black gram (Vigna mungo L.)," Microbiology Journal. 1(5): 159173.

Kannan, N. 1996. Laboratory Manual in General Microbiology, Palani Paramount Publication, India.

Karmegam, N and T.Daniel.2009. Investigating efficiency of Lampitomauritii (Kinberg) and Perionyxceylanensis for vermicomposting of different types of organic substrates. Environmentalist. 29, 287-300.

Martin JP, 1950. Use of acid, rose Bengal and Streptomycin in the plate method for estimating soil fungi. Soil Sci, 69:215232.

Prakash, M., Jayakumar, M. and Karmegam, N. 2009. Vermistabilization of paper mill sludge using the earthworm Perionyxceylanensis: influence on physico-chemical and microbiological status, Indian J. Appl. Microbiol. 10:2025.

Raja Sekar, K. and N. Karmegam, 2010. "Earthworm casts as an alternate carrier material for biofertilizers: assessment of endurance and viability of Azotobacter chroococcum, Bacillus megaterium and Rhizobium leguminosarum," Scientia Horticulturae. 124(2): 286-289.

Rangaswami, G. 1966. Agricultural Microbiology (Bombay; Asia Publ. House) pp: 413.

Rao, K. R., Mushan, L. C. and Ankaram, S. R. I. 2012. Influence of microorganisms in production of vermicompost from water hyacinth weed. Avishkar- Solapur University Research Journal. 2:14-21.

Sinha, R. K., Agarwal, S., Chauhan, K., Chandran, V. and Soni, B. K. 2010. "Vermiculture technology: reviving the dreams of Sir Charles Darwin for scientific use of earthworms in sustainable development programs," Journal of Technology and Investment. 1(3): 155-172.

Tiunov, A.V and Scheu, S. 2004. Carbon availability controls the growth of detritivorous (Lumbricidae) and their effect on $\mathrm{N}$ mineralisation. Oecologia, 138 (1), 83-90.

Tiwari, S.C., Tiwari, B.K and Mishra, R.R. 1989. Microbial populations, enzyme activities and nitrogen phosphorouspotassium enrichment in earthworm casts and in surrounding soil of pineapple plantation. J. of Biology and Fertility of soils 8:178-182.

Vlassak, K.L., Van, H and Duchateau, L. 1992. Isolation and characterization of fluorescent Pseudomonas associated with the roots of rice and banana grown in Srilanka. Plant and soil. 145: 51-63.

Wright, M.A. 1972. Factors governing ingestion by the earthworm Lumbricus terrestris with special reference to apple leaves. Ann.Biol.70: 175-188.

\section{How to cite this article:}

Sujan Biswas, Surajit Sarkar, Augustina Saha, Sankar Saha and Rahman, F.H. 2018. Study on Interaction of Earthworm with Bioagents during Vermicomposting. Int.J.Curr.Microbiol.App.Sci. 7(09): 300-308. doi: https://doi.org/10.20546/ijcmas.2018.709.037 